Geosci. Model Dev. Discuss., doi:10.5194/gmd-2016-165, 2016

Manuscript under review for journal Geosci. Model Dev.

Published: 15 August 2016

(c) Author(s) 2016. CC-BY 3.0 License.

\title{
Establishing relationship between measured and predicted soil water characteristics using SOILWAT model in three agro-ecological zones of Nigeria OrevaOghene Aliku* and Suarau O. Oshunsanya Department of Agronomy, University of Ibadan, Nigeria \\ *Corresponding Author: orevaoghenealiku@ gmail.com
}

7 Abstract

8 Soil available water (SAW) affects soil nutrients availability and consequently affects crop

9 performance. However, field determination of SAW for effective irrigated farming is 10 laborious, time consuming and expensive. Therefore, experiments were initiated at three 11 agro-ecological zones of Nigeria to compare the measured laboratory and predicted soil 12 available water using SOILWAT model for sustainable irrigated farming.

13 One hundred and eighty soil samples were collected from the three agro-ecological zones 14 (Savannah, Derived savannah and rainforest) of Nigeria and analysed for physical and 15 chemical properties. Soil texture and salinity were imputed into SOILWAT model (version 16 6.1.52) to predict soil physical properties for the three agro-ecological zones of Nigeria. 17 Measured and predicted values of field capacity, permanent wilting point and soil available water were compared using T-test.

Predicted soil textural classes by SOILWAT model were similar to the measured laboratory textural classes for savannah, derived savannah and rainforest zones. However, bulk density, maximum water holding capacity, permanent wilting point and soil available water were poorly predicted as significant $(\mathrm{p}<0.05)$ differences existed between measured and predicted values. Therefore, SOILWAT model could be adopted for predicting soil texture for savannah, derived savannah and rainforest zones of Nigeria. However, the model needs to be upgraded in order to accurately predict soil water characteristics of the aforementioned locations for sustainable irrigation planning.

Keywords: Field capacity, permanent wilting point, soil available water, soil texture, 
Geosci. Model Dev. Discuss., doi:10.5194/gmd-2016-165, 2016

Manuscript under review for journal Geosci. Model Dev.

Published: 15 August 2016

(c) Author(s) 2016. CC-BY 3.0 License.

\subsection{Introduction}

Water holding capacity is very important for assessing the water demand of vegetation, as well as for the recharge of the ground water storage. However, irregularities in rainfall amount and distribution resulting from the advent of climate, and intensive cultivation with severe erosion degradation have led to a decline in available land for crop production. Soil water is a basic requirement for plants survival because soil water determines to a very large extent the availability of plant nutrients to crops. Therefore, change in the soil water within a given soil profile or across a given landscape play a central role in soil available water, water conductivity, irrigation scheduling, drainage, evapotranspiration and the transport of salts and fertilizers.

As a result, several methods have been developed to estimate soil water characteristics of different types of soils for different agro-ecologies. Though, farmers in rural areas cultivate various crops by guessing the available moisture content of the soil by means of observation and feeling methods, one of the major drawbacks with this method is that the estimation of soil moisture is subjective and not exact (Schneekloth et al., 2007). Saxton and Rawls (2006) noted that estimation of soil water requirements would require soil water infiltration, conductivity, storage, and plant-water relationships. Common scientific methods of estimating soil water requirement involve direct or indirect determination in the laboratory. These methods use measurements or indicators of water content or a physical property that is sensitive to changes in water content.

On the other hand, laboratory methods of determining soil available water are costly and time consuming. Difficulty in describing the mechanical behaviour and water characteristics of soils has led to the often use of models with different approaches for monitoring soil moisture conditions (Van Genuchten and Leij, 1992). Guswa et al. (2002) reported that simple models for soil moisture dynamics, which do not resolve spatial variations in saturation, facilitates analytical expressions of soil and plant behaviour as functions of climate, soil and vegetation characteristics. Application of this knowledge is imperative for simulation of soil hydrological properties within natural landscapes. The Soil Water Characteristics Program (SOILWAT model) developed by Keith Saxton and Walter Rawls in cooperation with the Department of Biological Systems Engineering, Washington State University (Oyeogbe et al., 2012), estimates soil water potential, conductivity and water holding capability based on soil properties such as texture, organic matter, gravel, salinity, and compaction. The texture based method reported by Saxton et al. (1986) was largely based on the data set and analyses 
Geosci. Model Dev. Discuss., doi:10.5194/gmd-2016-165, 2016

Manuscript under review for journal Geosci. Model Dev.

Published: 15 August 2016

(c) Author(s) 2016. CC-BY 3.0 License.

of Rawls et al. (1982), who successfully applied the texture based method to a wide variety of analyses, particularly those of agricultural hydrology and water management using the SOILWAT model (Saxton and Willey, 2006). Other methods have provided similar results but with limited versatility (Stolte et al., 1994). Saxton and Rawls (2006) reported that estimating soil water hydraulic characteristics from readily available physical parameters has been a long-term goal of soil physicists and engineers. They further reported that many early trials were sufficiently successful with limited data sets to suggest that there were significant underlying relationships between soil water characteristics and parameters such as soil texture (Ahuja et al., 1999; Gijsman et al., 2002).

Recently, validation of the soil water characteristic model by comparing its predicted values with laboratory determined values have been based on soil texture and organic matter (Saxton and Rawls, 2006) at a particular soil depth within site(s) (Oyeogbe and Oluwasemire, 2013). Extrapolation of soil hydrological parameters predicted for a particular environment to another environment may be misleading due to differences in soil properties (soil heterogeneity). According to Guswa et al. (2002), proper application of models requires knowledge of the conditions under which the underlying simplifications are appropriate. Therefore, this study was carried out to compare laboratory and predicted SOILWAT model values of soil available water for sustainable irrigated farming in the three agro-ecological zones of Nigeria.

\subsection{Materials and methods}

\subsection{Study site}

The study was conducted in three agro-ecological zones of Nigeria; derived savannah - Ogun State (latitude $05^{\circ} 41^{\prime} \mathrm{N}$ and longitude $06^{\circ} 03^{\prime} \mathrm{E}$ ); savannah - Kogi State (latitude $06^{\circ} 49^{\prime} \mathrm{N}$ and longitude $06^{\circ} 11^{\prime} \mathrm{E}$ ) and rainforest - Edo State (latitude $06^{\circ} 41^{\prime} \mathrm{N}$ and longitude $06^{\circ} 36^{\prime}$ E). According to the international systems of soil classification FAO-UNESCO-ISRIC (1990), soils from Ogun State developed from Sedimentary rock while soils from Kogi State and Edo State developed from Basement complex rocks.

\section{Derived Savannah (Ogun state)}

This is predominantly grassy vegetation with a few scattered fire-resistant woody trees and date palm. It occupies an area of 493.36 ha. The soils are well drained and have a slope $\leq 2 \%$. The mean rainfall of $1150 \mathrm{~mm} /$ year and the temperature range of $20-35^{\circ} \mathrm{C}$. Derived savannah 
Geosci. Model Dev. Discuss., doi:10.5194/gmd-2016-165, 2016

Manuscript under review for journal Geosci. Model Dev.

Published: 15 August 2016

(c) Author(s) 2016. CC-BY 3.0 License.

is believed to have developed in areas which have been over-cultivated or subject to persistent burning especially during the dry season but the derived savannah in the area was brought about as a result of persistent high water table. The most common grasses in the project area are Panicum maximum and Imperata cylindrical. Pennisetum purpureum is found on the poorly drained areas or seasonally swampy areas. Very few scattered poor stands of cocoa and kola nuts were found in the area. Arable crops like cassava, yam, maize and leafy vegetables were found in the well-drained part of the project area. The soils are found over sedimentary rocks in Western Nigeria. Majority of the soils are formed over leached sandstone, without hard pan and with mottled clay. The parent materials (sandstones) are fairly well consolidated with mudstone bands, of Eocene age, Cretaceous age or loosely consolidated sandstones of Tertiary post-Eocene age. They are more or less ferruginous. These soils are generally termed "Acid sands" because of the sandy parent materials from which they are formed.

\section{Savannah}

This agro-ecological zone has a mean rainfall of $1200-1400 \mathrm{~mm} / \mathrm{year}$. It has a temperature range of $22-33^{\circ} \mathrm{C}$. The soils are fairly drained and are formed from crystalline basement complex rocks. The project area occupies an area of $69.83 \mathrm{ha}$ and has a slope $\leq 4.5 \%$. The type of vegetation is secondary forest.

\section{Rainforest}

The humid rainforest agro-ecological zone has a mean rainfall of $1200 \mathrm{~mm} / \mathrm{year}$ with a temperature of $15-34^{\circ} \mathrm{C}$. The soils are alluvial kandiudult deposits of River Niger, formed from underlying basement complex rocks. The sols are poorly drained and have a slope of $2-$ $3 \%$. The project area is 305.25 ha. The type of vegetation is secondary forest which consists of tree crops such as oil palm.

\subsection{Soil sampling}

Four modal soil profile pits $(150-200 \mathrm{~cm}$ deep) were sank at each mapping unit after soil identification and mapping was done by the rigid grid method. Soil samples were collected with the aid of soil auger from $0-30 \mathrm{~cm}$ and $30-60 \mathrm{~cm}$ (subsurface) of each profile, respectively. The profiles were described following FAO guidelines (FAO, 2006) at the agroecological zones of Nigeria.

\subsection{Soil analysis}

Composite samples were analysed for physical and chemical properties. Electrical conductivity was determined with a Conductivity Bridge in a 1:2 soil/water extract (Mclean, 
Geosci. Model Dev. Discuss., doi:10.5194/gmd-2016-165, 2016

Manuscript under review for journal Geosci. Model Dev.

Published: 15 August 2016

(c) Author(s) 2016. CC-BY 3.0 License.

1982). Soil $\mathrm{pH}$ was read from an EEL $\mathrm{pH}$ meter with glass electrodes inserted into 1:1 soil/water suspension (Mclean, 1982). Organic carbon was determined by the Walkley-Black dichromate titration method (Nelson and Sommers, 1982). Particle size analysis was by hydrometer method (Gee and Or, 2002), using sodium hexametaphosphate as dispersing agent. The functional relationship between soil wetness and matric suction was determined by means of a tension-table assembly in low suction range $(<0.07$ bars $)$, and pressure plate apparatus for the higher tension range (1 to 15 bars) (Hillel, 1971). Bulk density was measured by the core method in which core samples were oven-dried at $105^{\circ} \mathrm{C}$ until a constant weight was achieved. The dry weight of the soil was expressed as the fraction of the volume of the core as described by Grossman and Reinsch (2002).

\subsection{SOILWAT model description}

The Soil Water Characteristics Program (SOILWAT model) is a predictive system that was programmed for a graphical computerised model to provide easy application and rapid solutions in hydrologic analyses (Saxton and Rawls, 2006). The predictive equations used for the SOILWAT model were generated using an extensive laboratory data set of soil water characteristics obtained from the USDA/NRCS National Soil Characterisation database (Soil Survey Staff, 2004). The data included soil water content at 33- and 1500-kPa tensions; bulk densities; sand (S), silt and clay (C) particle sizes; and organic matter, that were developed with standard laboratory procedures (USDA-SCS, 1982).

According to Saxton and Rawls (2006), regression equations were then developed for moisture held at tensions of $1500,33,0$ to $33 \mathrm{kPa}$, and air-entry tensions. Air-entry values were estimated using the exponential form of the Campbell equation (Rawls et al., 1992), while saturation moisture $\left(\theta_{\mathrm{s}}\right)$ values were estimated from the reported sample bulk densities assuming a particle density value of $2.65 \mathrm{~g} \mathrm{~cm}^{-3}$ (Saxton and Rawls, 2006). The new moisture tension equations were combined with conductivity equations of Rawls et al. (1998) and additional equations for density, gravel, and salinity effects (Saxton and Rawls, 2006). They further reported that the resultant equations were then compared with three independent data sets representative of a wide range of soils to verify their capability for field applications. The new predictive equations used by the SOILWAT model to estimate soil water content at selected tensions of 1500, 33, 0 to 33, and $\psi_{\mathrm{e}} \mathrm{kPa}$ are summarized in Table 1, while the symbols for the parameters are defined in Table 2 (Saxton and Rawls, 2006). 
Geosci. Model Dev. Discuss., doi:10.5194/gmd-2016-165, 2016

Manuscript under review for journal Geosci. Model Dev.

Published: 15 August 2016

(c) Author(s) 2016. CC-BY 3.0 License.

The derived equations were incorporated into the graphical computer program to readily estimate soil hydrological characteristics. The predictive system (SOILWAT graphical computerised model) is available at http://hydrolab.arsusda.gov/soilwater/Index.htm.

\subsection{Model application}

The values for the independent and dependent variables were obtained and tabulated. The independent variables were percentage sand, percentage clay, percentage organic matter, percentage gravel, salinity, and compaction while dependent variables were wilting point, field capacity, available water, saturated hydraulic conductivity, saturation and bulk density. The derived independent variables were incorporated into the SOILWAT graphical computer program to estimate water holding and transmission characteristics (Fig. 1). Texture was selected from the textural triangle and slider bars were adjusted for organic matter, salinity, gravel, and compaction. The results were dynamically displayed in text boxes and on a moisture-tension and moisture-conductivity graph (Fig. 1) as the inputs were varied.

\subsection{Statistical analysis}

Data from observed and predicted methods were subjected to t-test statistic using the GenStat statistical software ( $8^{\text {th }}$ Edition). Soil moisture content at selected tensions of wilting point, field capacity, saturation and available water were also subjected to polynomial regression.

\subsection{Results and Discussion}

\subsection{Soil texture and salinity of different depths of the study area}

The soil texture and salinity status at the time of sampling are presented in Table 3, showing the particle size distribution down the profile. The results from laboratory analysis indicated an increase in the clay content and a decrease in the sand content down the depth in Savannah and Derived savannah, while rainforest had a decrease in clay content and an increase in sand content down the depth. At the depth of 0 to $60 \mathrm{~cm}$, the clay content increased from 6.75 to $14.9 \%$ in Savannah, 19.07 to $35.35 \%$ in derived savannah, and decreased in rainforest from 26.2 to $17.3 \%$. However, the sand fraction decreased from 92 to $84.2 \%$ and 76.6 to $61.3 \%$ in savannah and derived savannah, respectively, while in rainforest there was an increase in sand content from 64.2 to $78.4 \%$. The surface soils varied from loamy sand to sandy clay while the subsurface textures had a marginal change from sandy clay loam to sandy clay among the three agro-ecological zones of Nigeria. Salinity level was lower in surface soils $\left(0.07 \mathrm{dS} \mathrm{m}^{-1}\right)$ than subsurface soils $\left(0.23 \mathrm{dS} \mathrm{m}^{-1}\right)$ in savannah, while the reverse was the case 
Geosci. Model Dev. Discuss., doi:10.5194/gmd-2016-165, 2016

Manuscript under review for journal Geosci. Model Dev.

Published: 15 August 2016

(c) Author(s) 2016. CC-BY 3.0 License.

of derived savannah and rainforest. The result of the particle size distribution showed the dominance of sand sized particles in the three locations. With the exception of rainforest zone, the higher values of sand compared to silt and clay fractions is typical of soils in savannah and derived savannah agro-ecological zones of Nigeria (Babalola et al., 2000). Chris-Emenyonu and Onweremadu (2011) reported that these soils are formed largely from the coastal plain sands. Contrary to Ogeh and Ukodo (2012) silt content was found to decrease with increase in depth in all the agro-ecological zones. In the rainforest zone, the clay content was found to decrease with increase in depth as opposed to savannah and derived savannah zones. This result is in line with Ogeh and Ukodo (2012) who reported that the movement of clay through the process of illuviation may be responsible for the high clay content in the top soils of this region.

\subsection{Soil Available Water}

Table 4 showed the values of soil available water from the laboratory were significantly higher $(\mathrm{p}<0.05)$ than those predicted by the model in all the locations, indicating that SOILWAT model did not accurately predict soil available water for savannah, derived savannah and rainforest, respectively. In savannah, laboratory soil available water values increased with depth from 3.77 to $9.41 \mathrm{~cm}$, while the predicted value was $0.07 \mathrm{~cm}$ at the corresponding depths. In derived savannah, both laboratory and predicted soil available water (SAW) values increased with increase in depth. Laboratory SAW values increased from 4.71 to $9.38 \mathrm{~cm}$ and the predicted SAW values increased from 0.07 to $0.08 \mathrm{~cm}$. However, in rainforest, there was increase in the laboratory SAW values from 3.21 to $8.15 \mathrm{~cm}$, while the predicted SAW values decreased from 0.08 to $0.06 \mathrm{~cm}$ with depth. The best regression for available water was obtained for soils in derived savannah $\left(\mathrm{R}^{2}=0.44\right)$ indicating that SAW could be predicted using SOILWAT model (Fig. 2). However, savannah $\left(\mathrm{R}^{2}=0.25\right)$ and rainforest $\left(\mathrm{R}^{2}=0.13\right)$ had poor regression between laboratory and predicted SAW, suggesting that the SOILWAT model had poor SAW prediction for the aforementioned locations. These results may be due to the exclusion of organic matter data in the model adjustments, which could influence soil water. Saxton and Rawls (2006) stated that organic matter content of the soil play a major role in soil water retention.

\subsection{Bulk Density}

The values for measured (laboratory) and predicted bulk density are summarised in Table 5. Values obtained from the laboratory $\left(1.31\right.$ and $\left.1.41 \mathrm{~g} \mathrm{~cm}^{-3}\right)$ were significantly lower $(\mathrm{p}<0.05)$ 
Geosci. Model Dev. Discuss., doi:10.5194/gmd-2016-165, 2016

Manuscript under review for journal Geosci. Model Dev.

Published: 15 August 2016

(c) Author(s) 2016. CC-BY 3.0 License.

than the predicted values $\left(1.66\right.$ and $\left.1.55 \mathrm{~g} \mathrm{~cm}^{-3}\right)$ for savannah at $0-30 \mathrm{~cm}$ and $30-60 \mathrm{~cm}$ depths. However, derived savannah and rainforest bulk density values from the laboratory were lower at $0-30 \mathrm{~cm}$ depth and higher at $30-60 \mathrm{~cm}$ depth than the predicted values. It was noted that bulk density values were higher in soils from $30-60 \mathrm{~cm}$ depth than $0-30 \mathrm{~cm}$ depth for all locations. This could be ascribed to increase in soil compaction down the soil profile. Soil compaction has been reported to be associated with increase in bulk density which is one of the soil physical properties that may affect crop growth and yield (Lipiec et al., 1991; Lowery and Schuller, 1994; Mamman and Ohu, 1997). However, the predicted bulk density values at $30-60 \mathrm{~cm}$ depth was lower than $0-30 \mathrm{~cm}$ depth in savannah and derived savannah. This could be due to the absence of silt adjustments in the SOILWAT programmed textural triangle. Saxton and Rawls (2006) reported that the density values at the texture extremes (sands and clays) may be most likely to require adjustments. There was no significant difference between the observed and predicted bulk density values in rainforest zone.

\subsection{Field Capacity}

The measured field capacity values were lower than the predicted values in all the three locations (Table 6). Both measured and predicted field capacity values in savannah zone increased from 13.5 to $15.0 \%$, and 13.9 to $18.3 \%$ respectively for $0-60 \mathrm{~cm}$ depth. However, derived savannah soils showed a decrease in the measured field capacity values from 21.34 to $18.78 \%$, while the predicted values increased from 22.01 to $29.59 \%$ with depth. Both the measured and predicted values were not significant at $0-30 \mathrm{~cm}$ but decreased from 18.10 to $14.86 \%$ (measured) and 28.40 to $20.75 \%$ (predicted) in the rainforest zone. Figure 3 showed that the regression for field capacity with both $0-30 \mathrm{~cm}$ and $30-60 \mathrm{~cm}$ depth data in all locations were poor $\left(R^{2}=0.20\right)$. These results do not agree with Saxton and Rawls (2006) who reported higher $\mathrm{R}^{2}$ value of 0.63 due to the inclusion of appropriate local adjustments for organic matter, density and gravel in addition to salinity. They further reported that field capacity values will be most affected by organic matter adjustments, which has been reported to enhance soil water retention because of its hydrophilic nature and its positive influence on soil structure (Huntington, 2007).

\subsection{Hydraulic Conductivity}

The measured and predicted values for soil hydraulic conductivity under the three locations are summarised in Table 7. Measured values of 18.8 and $18.1 \mathrm{~cm} \mathrm{~s}^{-1}$ (savannah); 10.1 and 9.7 
Geosci. Model Dev. Discuss., doi:10.5194/gmd-2016-165, 2016

Manuscript under review for journal Geosci. Model Dev.

Published: 15 August 2016

(c) Author(s) 2016. CC-BY 3.0 License.

$\mathrm{cm} \mathrm{s}^{-1}$ (derived savannah); and 8.7 and $8.6 \mathrm{~cm} \mathrm{~s}^{-1}$ (rainforest) were significantly $(\mathrm{p}<0.05)$ higher than the predicted values of 4.8 and $1.3 \mathrm{~cm} \mathrm{~s}^{-1}$ (savannah); 0.6 and $0.2 \mathrm{~cm} \mathrm{~s}^{-1}$ (derived savannah); 0.4 and $1.0 \mathrm{~cm} \mathrm{~s}^{-1}$ (rainforest) at $0-30 \mathrm{~cm}$ and $30-60 \mathrm{~cm}$ soil depths, respectively. Both the measured and predicted hydraulic conductivity values for savannah and derived savannah were higher in $0-30 \mathrm{~cm}$ depth than $30-60 \mathrm{~cm}$ depth. This could be attributed to the increase in soil compaction down the profile. However, predicted saturated hydraulic conductivity for $0-30 \mathrm{~cm}$ depth was higher than $30-60 \mathrm{~cm}$ depth in rainforest. It also revealed that both measured and predicted hydraulic conductivity values decreased with soil depth in all locations except the predicted values which increased in rainforest zone. The significant difference between the predicted and measured SHC values may be due to the unavailability of soil density data for the simulation process. Carman (2002) reported that soil density affects the physical, mechanical and hydraulic properties of soils. Saxton and Rawls (2006) stated that soil density strongly affects soil structure and large pore distribution, consequently affecting saturated hydraulic conductivity. They further reported that a change in density factor will largely affect saturated hydraulic conductivity.

\subsection{Moisture Content (MC)}

Measured and predicted MC values are depicted in Table 8. The results showed that the measured MC values (18.79 and 18.87\%) were higher than the predicted (9.56 and $11.41 \%$ ) values in savannah soils. However, measured MC values of soils from derived savannah and rainforest were found to be lower than the predicted values. Measured MC values were 4.80 and $9.52 \%$ (derived savannah); and 3.40 and $9.36 \%$ (rainforest), while the predicted values were 14.71 and $21.32 \%$ (derived savannah); and 20.90 and $15.04 \%$ (rainforest) at $0-30 \mathrm{~cm}$ and $30-60 \mathrm{~cm}$ soil depths, respectively. Both measured and predicted MC values were significantly $(\mathrm{P}<0.05)$ higher in all locations at $30-60 \mathrm{~cm}$ depth, with the exception of rainforest zone. Several estimating methods developed in recent years have shown that generalized predictions can be made with usable, but variable accuracy (Rawls et al., 1982; Saxton et al., 1986; Stolte et al., 1994). Meissner (2004) reported a similar result that the inclusion of bulk density as an input to their model work improved the accuracy of soil water content estimation.

\subsection{Maximum water holding capacity (MWHC)}

Table 9 showed that the measured MWHC values were significantly $(\mathrm{p}<0.05)$ lower than the predicted MWHC values in all locations. Soils from savannah zone had the measured MWHC values of 18.85 and $18.56 \%$ and predicted MWHC values of 37.21 and $41.69 \%$. 
Geosci. Model Dev. Discuss., doi:10.5194/gmd-2016-165, 2016

Manuscript under review for journal Geosci. Model Dev.

Published: 15 August 2016

(c) Author(s) 2016. CC-BY 3.0 License.

However, derived savannah had measured MWHC values of 24.45 and $20.92 \%$ and predicted MWHC values of 44.33 and $48.44 \%$ while rainforest zone had observed MWHC values of 20.17 and $16.88 \%$ and predicted MWHC values of 46.97 and $42.95 \%$ at $0-30 \mathrm{~cm}$ and $30-$ $60 \mathrm{~cm}$ soil depths, respectively. The graphical results of regression for MWHC are shown in Figure 4 for all locations. The best regression graph was obtained for soils in savannah $\left(R^{2}=\right.$ $0.45)$, followed by derived savannah $\left(R^{2}=0.13\right)$ and least by rainforest $\left(R^{2}=0.05\right)$. This may be due to the fact that MWHC values may be based on factors which have no relationship with the correlation variables of texture. A similar result was also reported by Saxton and Rawls (2006) who reported that preliminary regression results for MWHC with two horizon data were poor $\left(R^{2}=0.25\right)$. Rawls (1983) and Grossman et al. (2001) explained that the poor regression result of the tested values may be due to the influence of factors such as tillage, root and worm activities, which are not part of the input parameters of the model.

\subsection{Wilting Point (WP)}

The laboratory measured and predicted WP values for the three locations are summarized in Table 10. The measured WP values were found to be significantly lower than the predicted values at $\mathrm{p}<0.05$ in all locations. Soils from $0-30 \mathrm{~cm}$ and $30-60 \mathrm{~cm}$ depth in savannah had observed WP values of 1.07 and $2.80 \%$, while the predicted values were 7.25 and $11.25 \%$, respectively, while observed WP values for derived savannah (2.81 and 5.45\%) and rainforest (4.80 and $3.44 \%$ ) were also lower than their respective predicted values at $0-30 \mathrm{~cm}$ and $30-$ $60 \mathrm{~cm}$ depths, respectively. Both the measured and predicted WP values were higher at the 30 $-60 \mathrm{~cm}$ soil depth in soils from savannah and derived savannah, while soils from rainforest had lower values at $30-60 \mathrm{~cm}$ soil depth. Figure 5 showed that the best wilting point regression was in savannah $\left(R^{2}=0.84\right)$, followed by derived savannah $\left(R^{2}=0.66\right)$ and least by rainforest $\left(\mathrm{R}^{2}=0.09\right)$. The result obtained in savannah is in line with Saxton and Rawls (2006) who reported $R^{2}$ value of 0.86 . They obtained the best regression with wilting point by using regression deviations as a guide in addition to slight adjustments of the clay content.

\subsection{Conclusions}

The SOILWAT model provides a quick visual display of the predicted textural classes that are similar to laboratory determined textural classes for savannah, derived savannah and rainforest zones of Nigeria. Also, the regression equations used to validate the integrity of the model parameters were strong for wilting point in the savannah and derived savannah agroecological zones. Results further showed that soil texture alone is not sufficient to predict soil water characteristics. However, additional variables such as organic matter, bulk density, 
Geosci. Model Dev. Discuss., doi:10.5194/gmd-2016-165, 2016

Manuscript under review for journal Geosci. Model Dev.

Published: 15 August 2016

(c) Author(s) 2016. CC-BY 3.0 License.

gravel and salinity are needed for accurate prediction of soil water parameters. In addition, measured and predicted variables (field capacity, wilting point and soil available water ) were significantly $(\mathrm{p}<0.05)$ different, suggesting that SOILWAT model needs some improvements for better prediction of soil moisture characteristics for irrigation planning and scheduling.

\section{Code and/or data availability}

SOILWAT model is a graphical computerised program developed with a predictive system that enhances the opportunity to integrate information on soil water characteristics into hydrologic analysis and water management decisions. It is available at http://hydrolab.arsusda.gov/soilwater/Index.htm, while the new predictive equations used to estimate soil water content in the model can be obtained from Saxton and Rawls (2006).

\section{Author contribution}

S. O. Oshunsanya designed the experiment while OrevaOghene Aliku carried it out and performed the simulation. OrevaOghene Aliku prepared the manuscript with contributions from S. O. Oshunsanya who also edited the manuscript.

\section{Acknowledgement}

The authors acknowledge the contributions of the laboratory technologist in the Department of Agronomy, University of Ibadan for their assistance in the various soil physical and hydrological analysis.

\section{References}

Ahuja, L. R., Rawls, W. J., Nielsen, D. R. and Williams, R. D. (1999). Determining soil hydraulic properties and their field variability from simpler measurements. $\mathrm{p}$. 1207-1233. In R. W. Skaggs and J. Van Schilfgaarde (ed.). Agricultural drainage. ASA Monogr. No. 38, ASA, Madison, WI.

Babalola, O., Zagal, E. and Ogunsola, O. (2000). Physical conditions and degradation of Nigerian soils. Proceedings of the $26^{\text {th }}$ Annual Conference of Soil Science Society of Nigeria, pp $96-111$.

Bouyoucos, G. H. (1951). A recalibration of the hydrometer method for making mechanical analysis of soils. Agron. J. 43: $434-438$.

Carman, K. (2002). Compaction characteristics of towed wheels on clay loam in a soil bin. Soil Till. Res., 65, 37-43. 
Geosci. Model Dev. Discuss., doi:10.5194/gmd-2016-165, 2016

Manuscript under review for journal Geosci. Model Dev.

Published: 15 August 2016

(c) Author(s) 2016. CC-BY 3.0 License.

Chris-Emenyonu, C. M. and Onweremadu, E. U. (2011). Indicators of erodibility of soils under different land use types in Imo State. Nigerian Journal of Agriculture, Food and Environment, 7(4):38-45.

FAO (2006). Guidelines for Soil Description (4th edition). FAO, Rome.

FAO-UNESCO-ISRIC (1990). FAO-UNESCO Soil Map of the World: Revised Legend. World Soil. Resources Report 60, Rome, 119 pp.

Gijsman, A. J., Jagtap, S. S. and Jones, J. W. (2002). Wading through a swamp of complete confusion: How to choose a method for estimating soil water retention parameters for crop models. Eur. J. Agron. 18:75 - 105.

Grossman, R. B., Harms, D. S., Seybold, C. A. and Herrick, J. E. (2001). Coupling usedependent and use-invariant data for soil quality evaluation in the United States. J. Soil Water Conserv. 56(1): $63-68$.

Guswa, A. J., Celia, M. A. and Rodriguez-Iturbe, I. (2002). Models for soil moisture dynamics in ecohydrology: A comparative study. Water Resources Research, Vol. 38(9), 1166, doi: 10.1029/2001WR000826.

Hillel, D. (1971). Soil and water. Physical principles and processes. Academic press. New York. 288pp.

Huntington, T. G. (2007). Available water capacity and soil organic matter. In: Encyclopedia of Soil Science, second edition. Taylor and Francis: New York. pp 139- 43.

Lipiec, J., Hakansson, I., Tarkiewiez, S. and Kossowski, J. (1991). Soil physical properties and growth of spring barley as related to the degree of compactness of two soils. Soil Till. Res., 19, 307-317.

Lowery, B., Schuler, R. T. (1994). Duration and effects of compaction on soil and plant growth in Wisconsin. Soil Till. Res., 29, 205-210.

Mamman, E., Ohu, J. O. (1997). Millet yield as affected by tractor traffic in a sandy loam soil in Borno State. Soil Till. Res. 42; 133-140.

McLean, E. O. (1982). Soil pH and lime requirement. In: Page et al (eds) Methods of Soil Analysis. Part2. Chemical and microbial properties. 2nd ed. Agron. monog. 9. ASA and SSSA, Madison, WI. Pp. 199-224. 
Geosci. Model Dev. Discuss., doi:10.5194/gmd-2016-165, 2016

Manuscript under review for journal Geosci. Model Dev.

Published: 15 August 2016

(c) Author(s) 2016. CC-BY 3.0 License.

Meissner, J. (2004). Relationship between soil properties of Mallee soils and parameters of two moisture characteristics models. Asssi Supersoil 2004 Symposium 8: Pedotransfer functions and soil inference systems.

Nelson, D. W. and Sommers, L. E. (1982). Total carbon, organic carbon and organic matter. In: Page et al (eds) Methods of Soil Analysis. Part2. 2nd ed. Agron. monog. 9. ASA and SSSA, Madison, WI. Pp. 539-579.

Ogeh, J. S. and Ukodo, E. (2012). Profile distribution of physical and chemical properties in soils of a toposequence in Benin, rainforest of Nigeria. Nigerian Journal of Basic and Applied Science, 20(1): 68-72.

Oyeogbe, I. A. and Oluwasemire, K. O. (2013). Evaluation of SOILWAT model for predicting soil water characteristics in south-western Nigeria. International Journal of soil science $8(2): 58-67$.

Oyeogbe, I. A., Oluwasemire, K. O. and Akinbola, G. E. (2012). Modelling soil water characteristics of an inland valley soil. Indian Journal of Agricultural Research 46(4): $317-323$.

Rawls, W. J. (1983). Estimating soil bulk density from particle size analyses and organic matter content. Soil Sci. 135:123 - 125 .

Rawls, W. J., Ahuja, L. R. and Brakensiek, D. L. (1992). Estimating soil hydraulic properties from soils data. p. 329-340. In M.Th. Van Genuchten et al. (ed.) Indirect methods for estimating the hydraulic properties of unsaturated soils. Univ. of California, Riverside, CA.

Rawls, W. J., Brakensiek, D. L. and Saxton, K. E. (1982). Estimation of soil water properties. Trans. ASAE 25:1316-1320.

Rawls, W. J., Gimenez, D. and Grossman, R. (1998). Use of soil texture, bulk density and slope of the water retention curve to predict saturated hydraulic conductivity. Trans. ASAE 41:983-988.

Saxton, K. E. and Rawls, W. J. (2006). Soil water characteristic estimates by texture and organic matter for hydrologic solutions. Soil Sci. Soc. Am. J. 70:1569-1578.

Saxton, K. E. and Willey, P. H. (2006). The SPAW model for agricultural field and pond hydrologic simulation. p. 401 - 435. In V.P. Singh and D.K. Frevert (ed.) Watershed models. CRC Press, Boca Raton, Fl. 
Geosci. Model Dev. Discuss., doi:10.5194/gmd-2016-165, 2016

Manuscript under review for journal Geosci. Model Dev.

Published: 15 August 2016

(c) Author(s) 2016. CC-BY 3.0 License.

Saxton, K. E., Rawls, W. J.,Romberger, J. S. and Papendick, R. I. (1986). Estimating generalized soil water characteristics from texture. Trans. ASAE 50:1031 - 1035.

Schneekloth, J., Bauder, T., Broner, I. and Waskom, R., (2007). Measurements Soil Moisture. http://www.extcolostate.edu/drought/soilmoisture.html (accessed on 24th September).

Soil Survey Staff. (2004). National soil characterization data. NRCS National Soil Survey Center, Lincoln, NE.

Stolte, J., Freijer, J. I., Bouten, W., Dirksen, C., Halbertsma, J. M., Van Dam, J. C., Van Den Berg, J. A., Veerman, G. J. and Wosten, J. H. M. (1994). Comparison of six methods to determine unsaturated soil hydraulic conductivity. Soil Sci. Soc. Am. J. 58:1596 1603.

USDA-SCS. (1982). Procedures for collecting soil samples and methods of analysis for soil survey. Soil Survey Investigations Report I, Washington, DC.

Van Genuchten, M. Th., and Leij, F. J. (1992). On estimating the hydraulic properties of unsaturated soils. p. 1-14. In M.Th. Van Genuchten et al. (ed.) indirect methods for estimating the hydraulic properties of unsaturated soils. Univ. of California, Riverside, CA. 
Geosci. Model Dev. Discuss., doi:10.5194/gmd-2016-165, 2016

Manuscript under review for journal Geosci. Model Dev.

Published: 15 August 2016

(c) Author(s) 2016. CC-BY 3.0 License.

Table 1: Summary of equations for soil water characteristics estimates. $\dagger$

\begin{tabular}{|c|c|c|c|}
\hline Variable & Equation & $R^{2} / \mathbf{S}_{\mathrm{e}}$ & Eq. \\
\hline \multicolumn{4}{|c|}{ Moisture Regressions } \\
\hline$\theta_{1500}$ & $\begin{aligned} \theta_{1500}= & \theta_{1500 t}+\left(0.14 \times \theta_{1500 t}-0.02\right) \\
\theta_{1500 t}=-0.024 \mathrm{~S}+0.487 \mathrm{C}+0.006 \mathrm{OM}+0.005(\mathrm{~S} \times \mathrm{OM})- & 0.013(\mathrm{C} \times \mathrm{OM})+0.068(\mathrm{~S} \times \mathrm{C})+0.031\end{aligned}$ & $0.86 / 0.02$ & 1 \\
\hline$\theta_{33}$ & $\begin{aligned} \theta_{33}= & \theta_{33 t}+\left[1.283\left(\theta_{33 t}\right)^{2}-0.374\left(\theta_{33 t}\right)-0.015\right] \\
\theta_{33 t}= & -0.251 \mathrm{~S}+0.195 \mathrm{C}+0.011 \mathrm{OM}+0.006(\mathrm{~S} \times \mathrm{OM})- \\
& 0.027(\mathrm{C} \times \mathrm{OM})+0.452(\mathrm{~S} \times \mathrm{C})+0.299\end{aligned}$ & $0.63 / 0.05$ & 2 \\
\hline$\theta_{\mathrm{S}-33}$ & $\begin{aligned} \theta_{\mathrm{S}-33}= & \theta_{(\mathrm{S}-33) t}+\left(0.636 \theta_{(\mathrm{S}-33) t}-0.107\right) \\
\theta_{(\mathrm{S}-33) t}= & 0.278 \mathrm{~S}+0.034 \mathrm{C}+0.022 \mathrm{OM}-0.018(\mathrm{~S} \times \mathrm{OM})- \\
& 0.027(\mathrm{C} \times \mathrm{OM})-0.584(\mathrm{~S} \times \mathrm{C})+0.078\end{aligned}$ & $0.36 / 0.06$ & 3 \\
\hline$\psi_{\mathrm{e}}$ & $\begin{aligned} \psi_{\mathrm{e}}= & \psi_{\mathrm{et}}+\left(0.02 \psi_{\mathrm{et}}^{2}-0.113 \psi_{\mathrm{et}}-0.70\right) \\
\psi_{\mathrm{et}}= & -21.67 \mathrm{~S}-27.93 \mathrm{C}-81.97 \theta_{\mathrm{s}-33}+71.12\left(\mathrm{~S} \times \theta_{\mathrm{S}-33}\right)+8.29(\mathrm{C} \\
& \left.\times \theta_{\mathrm{S}-33}\right)+14.05(\mathrm{~S} \times \mathrm{C})+27.16\end{aligned}$ & $0.78 / 2.9$ & 4 \\
\hline$\theta_{\mathrm{s}}$ & $\theta_{\mathrm{S}}=\theta_{33}+\theta_{(\mathrm{S}-33)}-0.097 \mathrm{~S}+0.043$ & $0.29 / 0.04$ & 5 \\
\hline$\rho_{\mathrm{N}}$ & \multicolumn{2}{|l|}{ Density Effects } & 6 \\
\hline$\rho_{D F}$ & $\rho_{\mathrm{DF}}=\rho_{\mathrm{N}} \times \mathrm{DF}$ & & 7 \\
\hline$\theta_{\mathrm{S}-\mathrm{DF}}$ & $\theta_{\mathrm{S}-\mathrm{DF}}=1-\left(\rho_{\mathrm{DF}} / 2.65\right)$ & & 8 \\
\hline$\theta_{33-\mathrm{DF}}$ & $\theta_{33-\mathrm{DF}}=\theta_{33}-0.2\left(\theta_{\mathrm{S}}-\theta_{\mathrm{S}-\mathrm{DF}}\right)$ & & 9 \\
\hline$\theta_{(\mathrm{S}-33) \mathrm{DF}}$ & & Moisture-Tension & 10 \\
\hline$\psi(1500-33)$ & $\psi_{\theta}=A(\theta)^{-B}$ & & 11 \\
\hline$\psi(33-\psi e)$ & $\psi_{\theta}=33.0-\left[\left(\theta-\theta_{33}\right)\left(33.0-\psi_{\mathrm{e}}\right) /\left(\theta_{\mathrm{s}}-\theta_{33}\right)\right]$ & & 12 \\
\hline$\theta_{(\psi \mathrm{e}-0)}$ & $\theta=\theta_{\mathrm{s}}$ & & 13 \\
\hline A & $A=\exp \left(\operatorname{In} 33+B \operatorname{In} \theta_{33}\right)$ & & 14 \\
\hline B & $\begin{array}{l}B=[\operatorname{In}(1500)-\operatorname{In}(33)] /\left[\operatorname{In}\left(\theta_{33}\right)-\operatorname{In}\left(\theta_{1500}\right)\right] \\
\text { Moisture-Conductivity }\end{array}$ & & 15 \\
\hline $\mathrm{K}_{\mathrm{S}}$ & $\mathrm{K}_{\mathrm{S}}=1930\left(\theta_{\mathrm{s}}-\theta_{33}\right)^{(3-\lambda)}$ & & 16 \\
\hline $\mathrm{K}_{\theta}$ & $\mathrm{K}_{\theta}=\mathrm{K}_{\mathrm{s}}\left(\theta / \theta_{\mathrm{s}}\right)^{[3+(2 / \lambda)]}$ & & 17 \\
\hline$\Lambda$ & $\begin{array}{l}\lambda=1 / B \\
\text { Gravel Effects }\end{array}$ & & 18 \\
\hline$R_{v}$ & $R_{v}=\left(\alpha R_{\mathrm{w}}\right) /\left[1-R_{\mathrm{w}}(1-\alpha)\right]$ & & 19 \\
\hline$\rho_{\mathrm{B}}$ & $\rho_{\mathrm{B}}=\rho_{\mathrm{N}}\left(1-R_{v}\right)+\left(R_{v} \times 2.65\right)$ & & 20 \\
\hline $\mathrm{PAW}_{\mathrm{B}}$ & $\mathrm{PAW}_{\mathrm{B}}=\mathrm{PAW}\left(1-R_{v}\right)$ & & 21 \\
\hline$K_{b} / K_{s}$ & $K_{b} / K_{s}=\frac{1-R_{\mathrm{w}}}{\left[1-R_{\mathrm{W}}(1-3 \alpha / 2)\right]}$ & & 22 \\
\hline \multicolumn{4}{|c|}{ Salinity Effects } \\
\hline $\begin{array}{l}\Psi_{\mathrm{O}} \\
\Psi_{\mathrm{O} \theta}\end{array}$ & $\begin{array}{l}\Psi_{\mathrm{O}}=36 \mathrm{EC} \\
\Psi_{\mathrm{O} \theta}=\frac{\theta_{\mathrm{S}}}{\theta}(36 \mathrm{EC})\end{array}$ & & $\begin{array}{l}23 \\
24\end{array}$ \\
\hline
\end{tabular}


Geosci. Model Dev. Discuss., doi:10.5194/gmd-2016-165, 2016

Manuscript under review for journal Geosci. Model Dev.

Published: 15 August 2016

(c) Author(s) 2016. CC-BY 3.0 License.

Table 2: Definitions for soil moisture characteristics equation symbols

\begin{tabular}{|c|c|}
\hline Symbol & Definition \\
\hline $\mathrm{A}, \mathrm{B}$ & Coefficients of moisture-tension, Eq. [11] \\
\hline $\mathrm{C}$ & Clay, \%w \\
\hline $\mathrm{DF}$ & Density adjustment Factor (0.9-1.3) \\
\hline $\mathrm{EC}$ & Electrical conductance of a saturated soil extract, $\mathrm{dS} \mathrm{m} \mathrm{m}^{-1}\left(\mathrm{dS} / \mathrm{m}=\right.$ mili-mho $\left.\mathrm{cm}^{-1}\right)$ \\
\hline FC & Field Capacity moisture $(33 \mathrm{kPa}), \% \mathrm{v}$ \\
\hline $\mathrm{OM}$ & Organic Matter, \%v \\
\hline PAW & Plant Available moisture (33-1500 kPa, matric soil), \%v \\
\hline PAW $_{B}$ & Plant Available moisture (33-1500 kPa, bulk soil), \%v \\
\hline $\mathrm{S}$ & Sand, \%w \\
\hline SAT & Saturation moisture $(0 \mathrm{kPa}), \% \mathrm{v}$ \\
\hline WP & Wilting point moisture $(1500 \mathrm{kPa}), \% \mathrm{v}$ \\
\hline$\theta_{\psi}$ & Moisture at tension $\psi, \% \mathrm{v}$ \\
\hline$\theta_{1500 t}$ & $1500 \mathrm{kPa}$ moisture, first solution, \% v \\
\hline$\theta_{1500}$ & $1500 \mathrm{kPa}$ moisture, normal density, \%v \\
\hline$\theta_{33 \mathrm{t}}$ & $33 \mathrm{kPa}$ moisture, first solution, \% v \\
\hline$\theta_{33}$ & $33 \mathrm{kPa}$ moisture, normal density, \%v \\
\hline$\theta_{33-\mathrm{DF}}$ & $33 \mathrm{kPa}$ moisture, adjusted density, \%v \\
\hline$\theta_{(\mathrm{S}-33) \mathrm{t}}$ & SAT-33 kPa moisture, first solution, $\% \mathrm{v}$ \\
\hline$\theta_{(\mathrm{S}-33)}$ & SAT-33 kPa moisture, normal density, \%v \\
\hline$\theta_{(\mathrm{S}-33) \mathrm{DF}}$ & SAT-33 kPa moisture, adjusted density, \%v \\
\hline$\theta_{\mathrm{s}}$ & Saturated moisture $(0 \mathrm{kPa})$, normal density, $\% \mathrm{v}$ \\
\hline$\theta_{\mathrm{S}-\mathrm{DF}}$ & Saturated moisture $(0 \mathrm{kPa})$, adjusted density, \%v \\
\hline$\psi_{\theta}$ & Tension at moisture $\theta, \mathrm{kPa}$ \\
\hline$\psi_{\text {et }}$ & Tension at air entry, first solution, $\mathrm{kPa}$ \\
\hline$\psi_{\mathrm{e}}$ & Tension at air entry (bubbling pressure), $\mathrm{kPa}$ \\
\hline $\mathrm{K}_{\mathrm{S}}$ & Saturated hydraulic conductivity (matric soil), $\mathrm{mm} \mathrm{h}^{-1}$ \\
\hline $\mathrm{K}_{\mathrm{b}}$ & Saturated hydraulic conductivity (bulk soil), $\mathrm{mm} \mathrm{h}^{-1}$ \\
\hline $\mathrm{K}_{\theta}$ & Unsaturated conductivity at moisture $\theta, \mathrm{mm} \mathrm{h}^{-1}$ \\
\hline$\rho_{\mathrm{N}}$ & Normal density, $\mathrm{g} \mathrm{cm}^{-3}$ \\
\hline$\rho_{\mathrm{B}}$ & Bulk soil density (matric plus gravel), $\mathrm{g} \mathrm{cm}^{-3}$ \\
\hline$\rho_{\mathrm{DF}}$ & Adjusted density, $\mathrm{g} \mathrm{cm}^{-3}$ \\
\hline$\lambda$ & Slope of logarithmic tension-moisture curve \\
\hline$\alpha$ & Matric soil density/gravel density $(2.65)=\rho / 2.65$ \\
\hline $\mathrm{R}_{\mathrm{V}}$ & Volume fraction of gravel (decimal), $\mathrm{g} \mathrm{cm}^{-3}$ \\
\hline $\mathrm{R}_{\mathrm{w}}$ & Weight fraction of gravel (decimal), $\mathrm{g} \mathrm{g}^{-1}$ \\
\hline$\Psi_{\mathrm{O}}$ & Osmotic potential at $\theta=\theta_{\mathrm{s}}, \mathrm{kPa}$ \\
\hline$\Psi_{\mathrm{O} \theta}$ & Osmotic potential at $\theta<\theta_{\mathrm{s}}, \mathrm{kPa}$ \\
\hline
\end{tabular}

$\% \mathrm{w}=$ decimal percent by weight basis, $\% \mathrm{v}=$ decimal percent by volume basis. 
Geosci. Model Dev. Discuss., doi:10.5194/gmd-2016-165, 2016

Manuscript under review for journal Geosci. Model Dev.

Published: 15 August 2016

(c) Author(s) 2016. CC-BY 3.0 License.

471

Table 3: Observed and predicted textural classes for values of sand, silt and clay

\begin{tabular}{|c|c|c|c|c|c|c|c|}
\hline \multirow[t]{2}{*}{ Location } & \multirow{2}{*}{$\begin{array}{l}\text { Soil depth } \\
(\mathrm{cm})\end{array}$} & \multirow{2}{*}{$\begin{array}{l}\text { Salinity } \\
(\mathrm{dS} / \mathrm{m})\end{array}$} & Sand & Silt & Clay & \multicolumn{2}{|c|}{ Textural class } \\
\hline & & & \multicolumn{3}{|c|}{ Mean weight (\%) } & Laboratory & SOILWAT \\
\hline \multirow[t]{2}{*}{ Savannah } & $0-30$ & 0.07 & 92 & 2.25 & 6.75 & $\mathrm{~S}$ & $S-L S$ \\
\hline & $30-60$ & 0.23 & 84.2 & 1.90 & 14.9 & $\mathrm{LS}-\mathrm{SL}$ & $\mathrm{LS}-\mathrm{SL}$ \\
\hline \multirow[t]{2}{*}{ Derived savannah } & $0-30$ & 1.02 & 76.57 & 5.79 & 19.07 & $\mathrm{LS}-\mathrm{SC}$ & $\mathrm{LS}-\mathrm{C}$ \\
\hline & $30-60$ & 0.05 & 61.25 & 4.45 & 35.35 & $\mathrm{SCL}-\mathrm{SC}$ & $\mathrm{SCL}-\mathrm{SC}$ \\
\hline \multirow[t]{2}{*}{ Rainforest } & $0-30$ & 7.74 & 64.17 & 9.75 & 26.17 & $\mathrm{LS}-\mathrm{SC}$ & $\mathrm{LS}-\mathrm{C}$ \\
\hline & $30-60$ & 5.94 & 78.37 & 4.37 & 17.26 & $S-S C L$ & $S-S C$ \\
\hline
\end{tabular}

Note: S: Sand; LS: Loamy sand; SL: Sandy loam; SC: Sandy clay; SCL: Sandy clay loam; C: Clay

472

473

474

475

477

Table 4: Comparison of soil available water values from laboratory and SOILWAT model for the three agro-ecological zones of Nigeria

\begin{tabular}{|c|c|c|c|c|c|}
\hline \multirow[t]{2}{*}{ Location } & Depth $(\mathrm{cm})$ & Laboratory & SOILWAT & \multirow[t]{2}{*}{ S.E. \pm} & \multirow[t]{2}{*}{$\mathrm{CV} \%$} \\
\hline & & \multicolumn{2}{|c|}{ Soil available water $(\%)$} & & \\
\hline \multirow[t]{2}{*}{ Savannah } & $0-30$ & 3.77 & 0.07 & $1.43 * *$ & 74.30 \\
\hline & $30-60$ & 9.41 & 0.07 & $3.09 * *$ & 65.20 \\
\hline \multirow[t]{2}{*}{ Derived savannah } & $0-30$ & 4.71 & 0.07 & $1.41 * *$ & 59.00 \\
\hline & $30-60$ & 9.38 & 0.08 & $2.68 * *$ & 56.60 \\
\hline \multirow[t]{2}{*}{ Rainforest } & $0-30$ & 3.21 & 0.08 & $0.72 * *$ & 43.90 \\
\hline & $30-60$ & 8.15 & 0.06 & $1.89 * *$ & 46.0 \\
\hline
\end{tabular}

** Significant at $\mathrm{p}=0.01$ 
Geosci. Model Dev. Discuss., doi:10.5194/gmd-2016-165, 2016

Manuscript under review for journal Geosci. Model Dev.

Published: 15 August 2016

(c) Author(s) 2016. CC-BY 3.0 License.

Table 5: Comparing bulk density values from laboratory and SOILWAT model for the three agro-ecological zones of Nigeria

\begin{tabular}{cccccc}
\hline Location & Depth $(\mathrm{cm})$ & Laboratory & SOILWAT & S.E. \pm & CV\% \\
\cline { 3 - 4 } & & \multicolumn{2}{c}{ Bulk density $\left(\mathrm{g} \mathrm{cm}^{-3}\right)$} & & \\
\hline Savannah & $0-30$ & 1.31 & 1.66 & $0.09^{* *}$ & 6.40 \\
& $30-60$ & 1.41 & 1.55 & $0.13^{*}$ & 8.50 \\
\multirow{2}{*}{ Derived savannah } & $0-30$ & 1.28 & 1.48 & $0.16^{* *}$ & 11.30 \\
& $30-60$ & 1.52 & 1.37 & $0.15^{* *}$ & 10.40 \\
Rainforest & $0-30$ & 1.34 & 1.41 & $0.14 \mathrm{~ns}$ & 10.10 \\
& $30-60$ & 1.57 & 1.51 & $0.17 \mathrm{~ns}$ & 10.70 \\
\hline
\end{tabular}

** Significant at $\mathrm{p}=0.01 ; *$ Significant at $\mathrm{p}=0.05$; ns: not significant at $\mathrm{p}=0.05$

Table 6: Comparing laboratory determined field capacity and SOILWAT predicted field capacity values from agro-ecological zones of Nigeria

\begin{tabular}{cccccc}
\hline Location & Depth $(\mathrm{cm})$ & Laboratory & SOILWAT & S.E. \pm & CV\% \\
\cline { 3 - 4 } & & \multicolumn{2}{c}{ Field capacity $(\%)$} & & \\
\hline Savannah & $0-30$ & 13.57 & 13.99 & $2.26 \mathrm{~ns}$ & 16.40 \\
& $30-60$ & 15.07 & 18.39 & $2.15^{* *}$ & 12.80 \\
\multirow{2}{*}{ Derived savannah } & $0-30$ & 21.34 & 22.01 & $3.78 \mathrm{~ns}$ & 17.50 \\
& $30-60$ & 18.78 & 29.59 & $4.20^{* *}$ & 17.40 \\
Rainforest & $0-30$ & 18.10 & 28.40 & $6.43^{* *}$ & 27.60 \\
& $30-60$ & 14.86 & 20.75 & $4.54^{* *}$ & 25.50 \\
\hline
\end{tabular}

** Significant at $\mathrm{p}=0.01 ; \mathrm{ns}$ : not significant at $\mathrm{p}=0.05$ 
Geosci. Model Dev. Discuss., doi:10.5194/gmd-2016-165, 2016

Manuscript under review for journal Geosci. Model Dev.

Published: 15 August 2016

(c) Author(s) 2016. CC-BY 3.0 License.

Table 7: Comparison of laboratory determined saturated hydraulic conductivity values and SOILWAT model for the three agro-ecological zones of Nigeria

\begin{tabular}{|c|c|c|c|c|c|}
\hline \multirow[t]{2}{*}{ Location } & \multirow[t]{2}{*}{ Depth $(\mathrm{cm})$} & Laboratory & SOILWAT & \multirow[t]{2}{*}{ S.E. \pm} & \multirow[t]{2}{*}{$\mathrm{CV} \%$} \\
\hline & & \multicolumn{2}{|c|}{$\mathrm{Ks}\left(\mathrm{cm} \mathrm{s}^{-1}\right)$} & & \\
\hline \multirow[t]{2}{*}{ Savannah } & $0-30$ & 18.80 & 4.80 & $5.80 * *$ & 49.20 \\
\hline & $30-60$ & 18.10 & 1.30 & $5.65 * *$ & 58.50 \\
\hline \multirow[t]{2}{*}{ Derived savannah } & $0-30$ & 10.10 & 0.60 & $6.52 * *$ & 121.30 \\
\hline & $30-60$ & 9.70 & 0.20 & $6.41 * *$ & 129.50 \\
\hline \multirow[t]{2}{*}{ Rainforest } & $0-30$ & 8.70 & 0.44 & $3.75 * *$ & 82.20 \\
\hline & $30-60$ & 8.64 & 1.09 & $3.71 * *$ & 76.3 \\
\hline
\end{tabular}

** Significant at $\mathrm{p}=0.01$

489

490

Table 8: A comparison of soil moisture content values of laboratory and SOILWAT model for the three ago-ecological zones of Nigeria

\begin{tabular}{|c|c|c|c|c|c|}
\hline \multirow[t]{2}{*}{ Location } & \multirow[t]{2}{*}{ Depth $(\mathrm{cm})$} & Laboratory & SOILWAT & \multirow[t]{2}{*}{ S.E. \pm} & \multirow[t]{2}{*}{$\mathrm{CV} \%$} \\
\hline & & \multicolumn{2}{|c|}{$\mathrm{MC}(\%)$} & & \\
\hline \multirow[t]{2}{*}{ Savannah } & $0-30$ & 18.79 & 9.56 & $2.26^{* *}$ & 16.00 \\
\hline & $30-60$ & 18.87 & 11.41 & $2.22 * *$ & 14.70 \\
\hline \multirow[t]{2}{*}{ Derived savannah } & $0-30$ & 4.80 & 14.71 & $2.88 * *$ & 29.60 \\
\hline & $30-60$ & 9.52 & 21.32 & $4.14 * *$ & 26.90 \\
\hline \multirow[t]{2}{*}{ Rainforest } & $0-30$ & 3.40 & 20.90 & $5.23 * *$ & 43.10 \\
\hline & $30-60$ & 9.36 & 15.04 & $4.42 * *$ & 36.30 \\
\hline
\end{tabular}

** Significant at $\mathrm{p}=0.01$
491

492 
Geosci. Model Dev. Discuss., doi:10.5194/gmd-2016-165, 2016

Manuscript under review for journal Geosci. Model Dev.

Published: 15 August 2016

(c) Author(s) 2016. CC-BY 3.0 License.

Table 9: A comparison of laboratory determined and SOILWAT predicted maximum water holding capacity for the three agro-ecological zones of Nigeria

\begin{tabular}{cccccc}
\hline Location & Depth $(\mathrm{cm})$ & Laboratory & SOILWAT & S.E. \pm & CV\% \\
\cline { 3 - 4 } & & \multicolumn{2}{c}{ MWHC (\%) } & \\
\hline Savannah & $0-30$ & 18.85 & 37.21 & $3.84^{* *}$ & 13.70 \\
& $30-60$ & 18.56 & 41.69 & $2.57^{* *}$ & 8.50 \\
Derived savannah & $0-30$ & 24.45 & 44.33 & $3.22^{* *}$ & 9.30 \\
& $30-60$ & 20.92 & 48.44 & $3.15^{* *}$ & 9.10 \\
Rainforest & $0-30$ & 20.17 & 46.97 & $4.15^{* *}$ & 12.30 \\
& $30-60$ & 16.88 & 42.95 & $3.88^{* *}$ & 13.00 \\
\hline
\end{tabular}

** Significant at $\mathrm{p}=0.01$

494

495

Table 10: A comparison of laboratory determined and SOILWAT predicted values for wilting point for the three agro-ecological zones of Nigeria

\begin{tabular}{cccccc}
\hline Location & Depth $(\mathrm{cm})$ & Laboratory & SOILWAT & S.E. \pm & CV\% \\
\cline { 2 - 4 } & & \multicolumn{3}{c}{ WP $(\%)$} \\
\hline Savannah & $0-30$ & 1.07 & 7.25 & $1.19^{* *}$ & 28.60 \\
& $30-60$ & 2.80 & 11.25 & $1.27^{* *}$ & 18.10 \\
Derived savannah & $0-30$ & 2.81 & 14.70 & $2.53^{* *}$ & 28.90 \\
& $30-60$ & 5.45 & 21.31 & $3.01^{* *}$ & 22.50 \\
Rainforest & $0-30$ & 4.80 & 20.70 & $5.12^{* *}$ & 40.10 \\
& $30-60$ & 3.44 & 14.67 & $4.23^{* *}$ & 46.70 \\
\hline
\end{tabular}

** Significant at $\mathrm{p}=0.01$
496

497

498

499

500 
Geosci. Model Dev. Discuss., doi:10.5194/gmd-2016-165, 2016

Manuscript under review for journal Geosci. Model Dev.

Published: 15 August 2016

(c) Author(s) 2016. CC-BY 3.0 License. 
Geosci. Model Dev. Discuss., doi:10.5194/gmd-2016-165, 2016

Manuscript under review for journal Geosci. Model Dev.

Published: 15 August 2016

(c) Author(s) 2016. CC-BY 3.0 License.

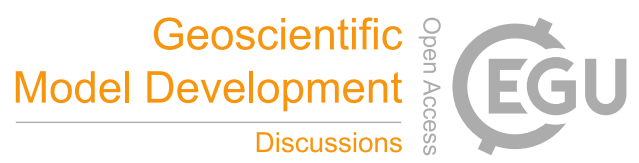

(c) (1)

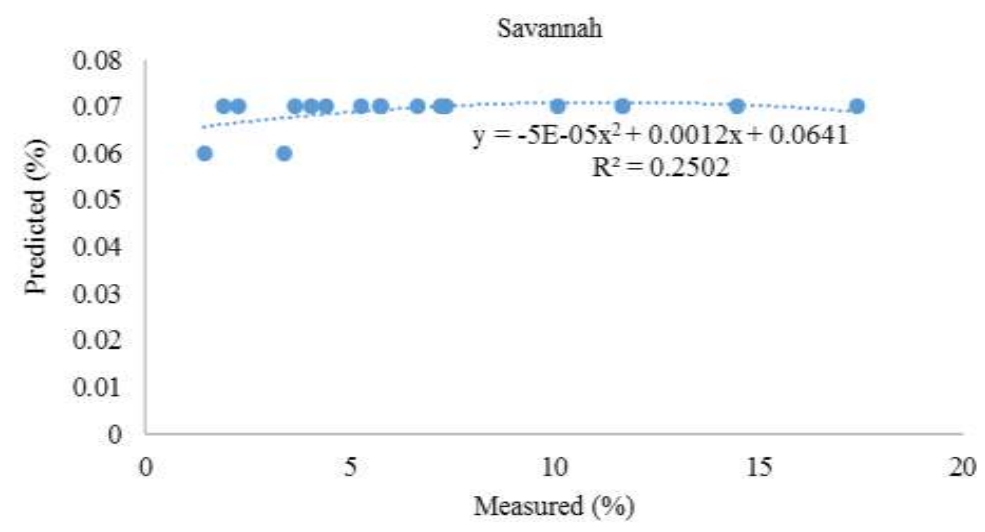

523

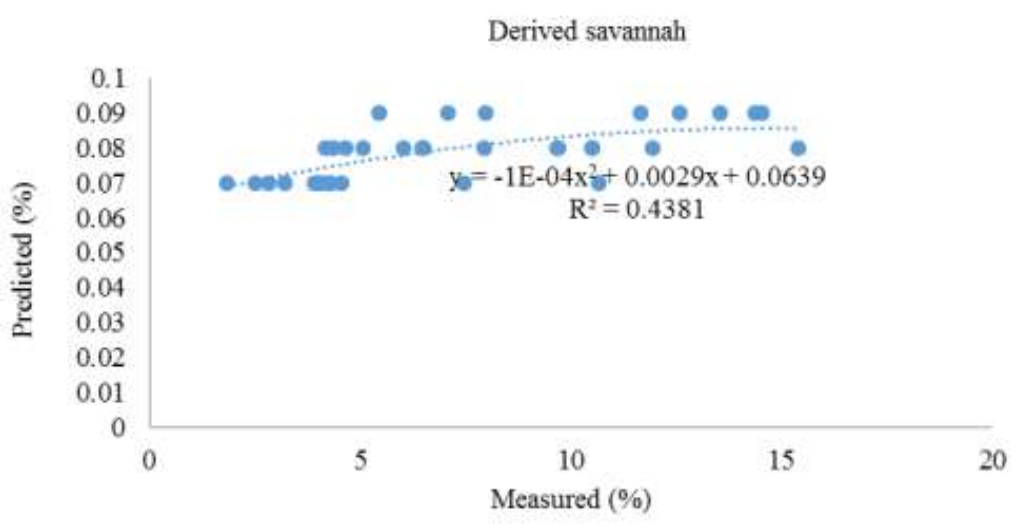

524

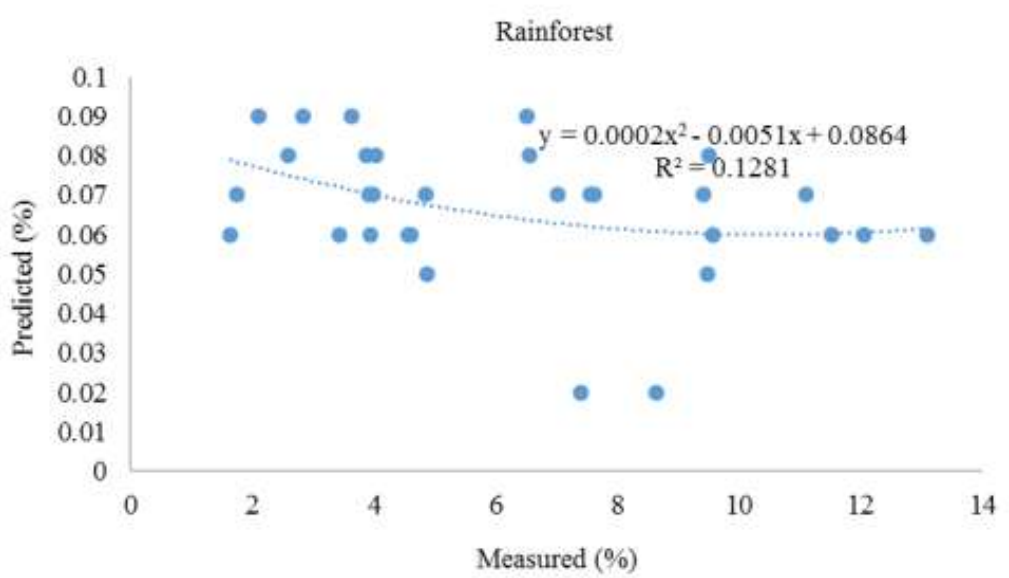

526 Fig. 2: Relationship between measured and predicted soil available water expressed by 527 polynomial regression 
Geosci. Model Dev. Discuss., doi:10.5194/gmd-2016-165, 2016

Manuscript under review for journal Geosci. Model Dev.

Published: 15 August 2016

(c) Author(s) 2016. CC-BY 3.0 License.

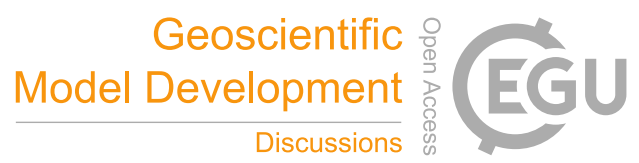

(c) (1)

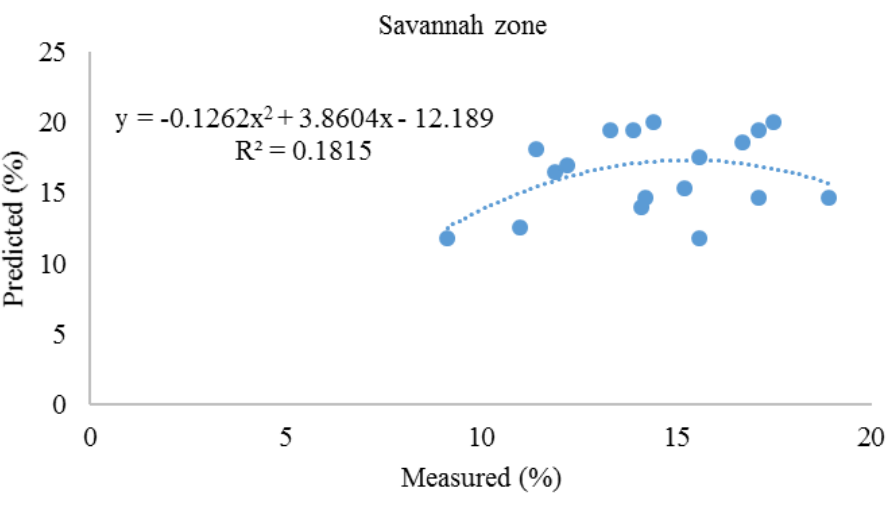

528

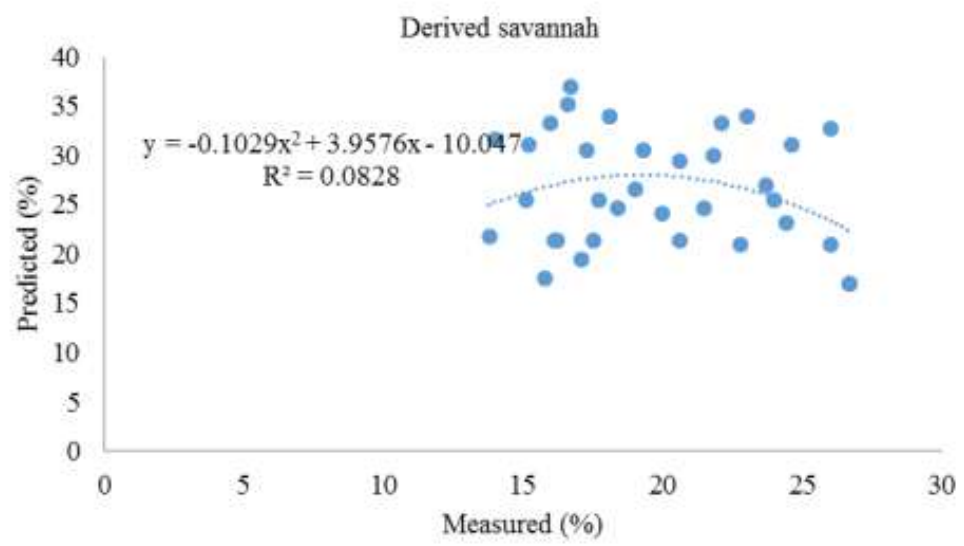

529

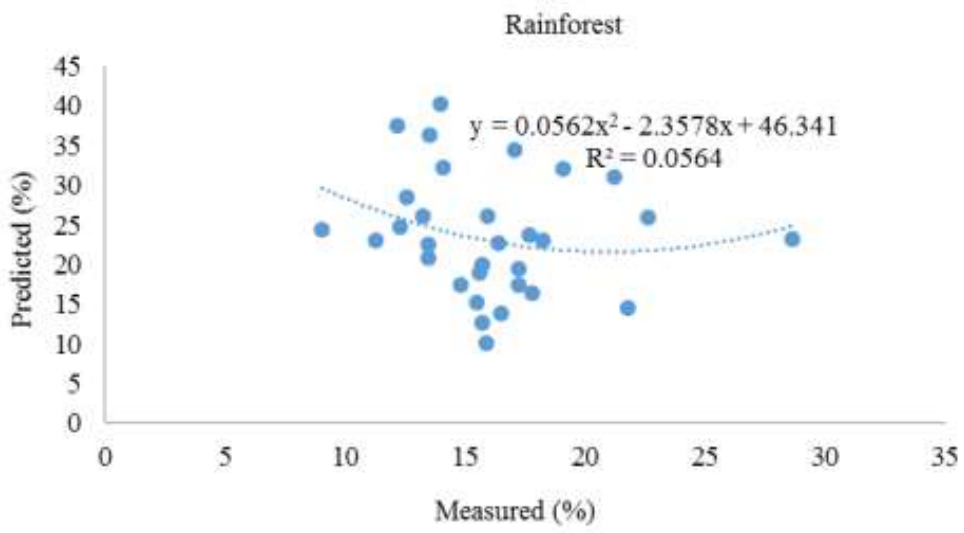

530

531 Fig. 3: Relationship between measured and predicted field capacity expressed by polynomial regression 
Geosci. Model Dev. Discuss., doi:10.5194/gmd-2016-165, 2016

Manuscript under review for journal Geosci. Model Dev.

Published: 15 August 2016

(c) Author(s) 2016. CC-BY 3.0 License.
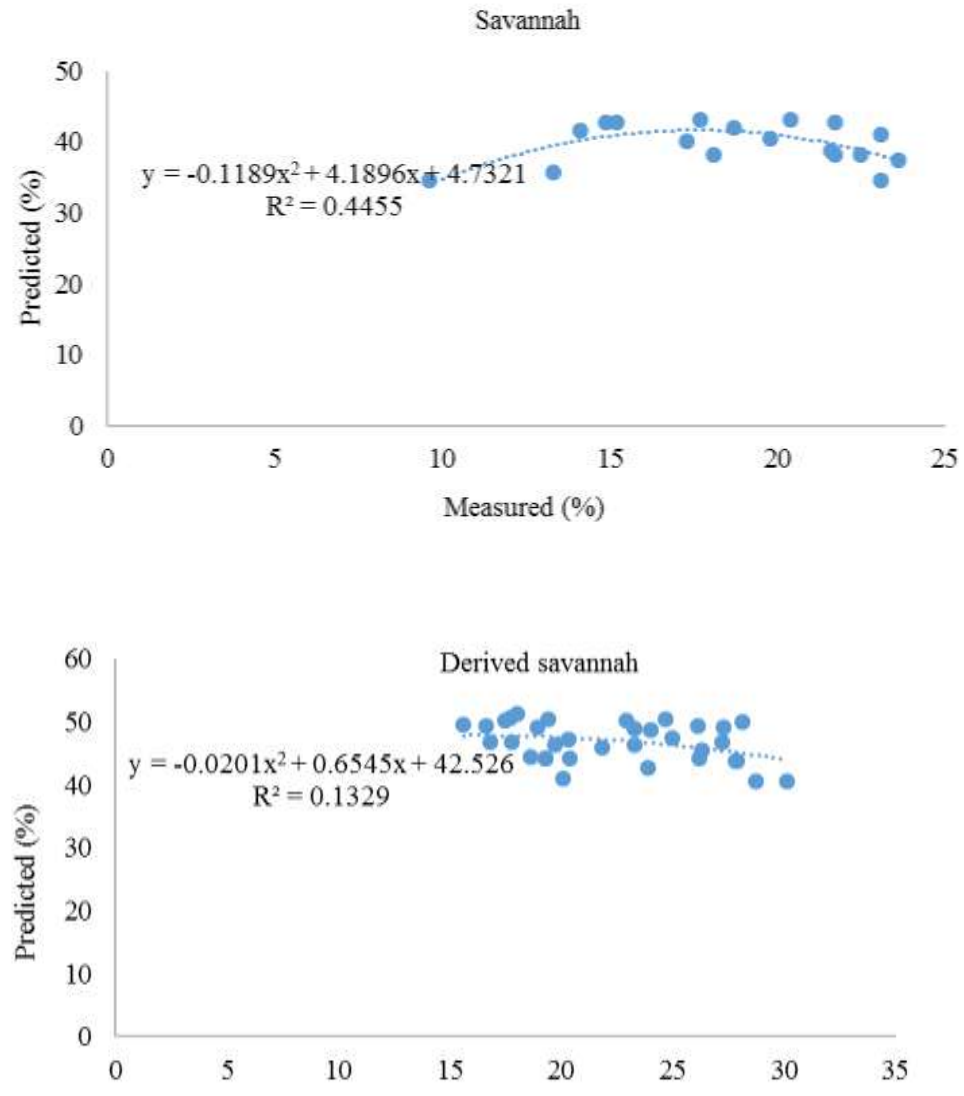

534

Measured (\%)

535

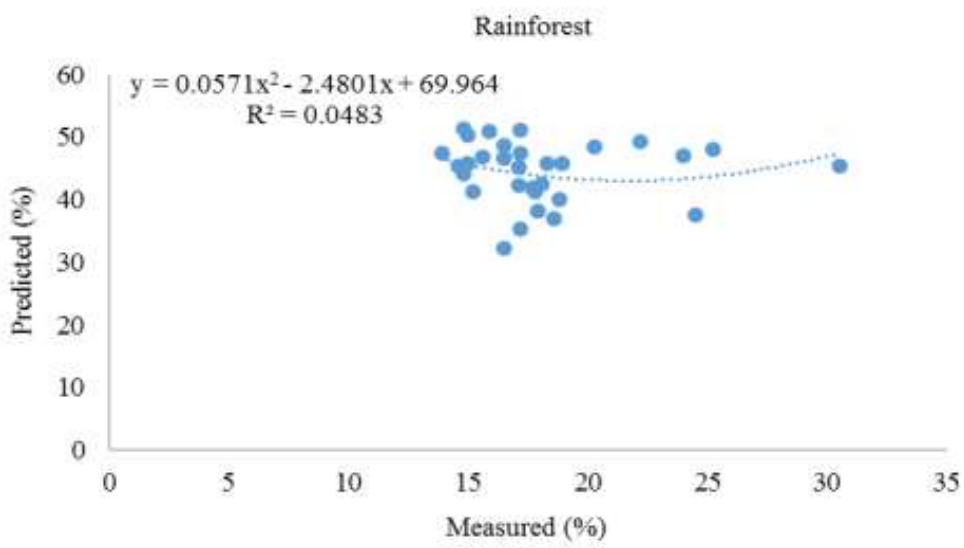


Geosci. Model Dev. Discuss., doi:10.5194/gmd-2016-165, 2016

Manuscript under review for journal Geosci. Model Dev.

Published: 15 August 2016

(c) Author(s) 2016. CC-BY 3.0 License.

(c) (1)

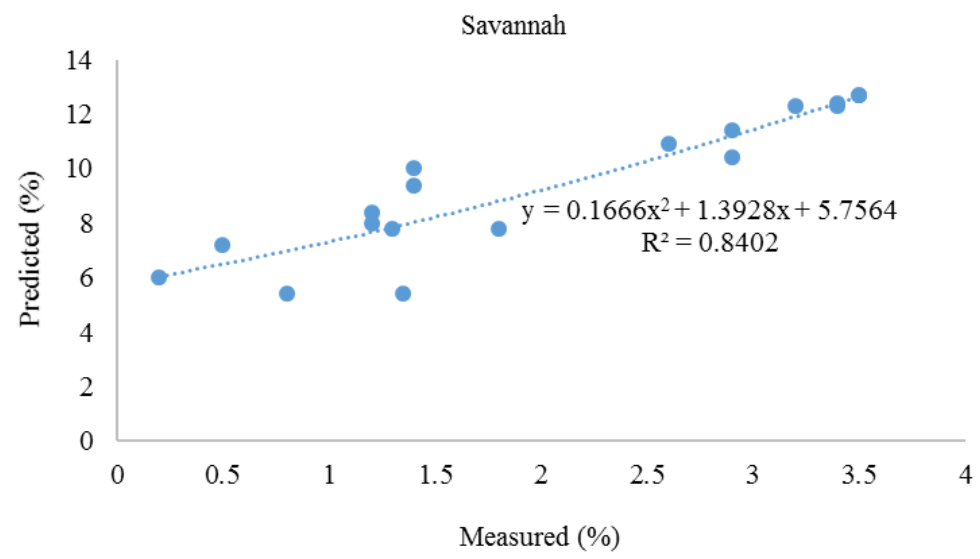

539

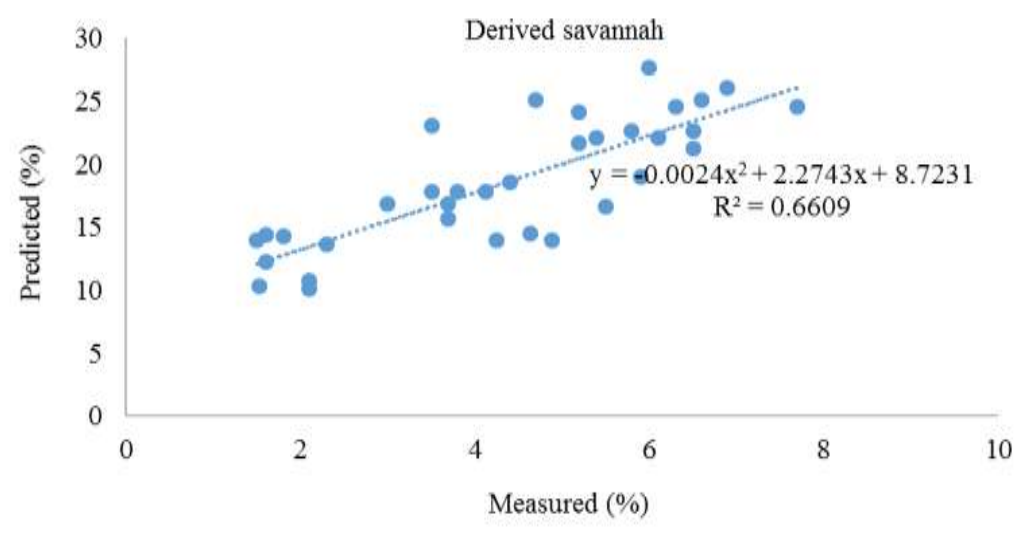

540

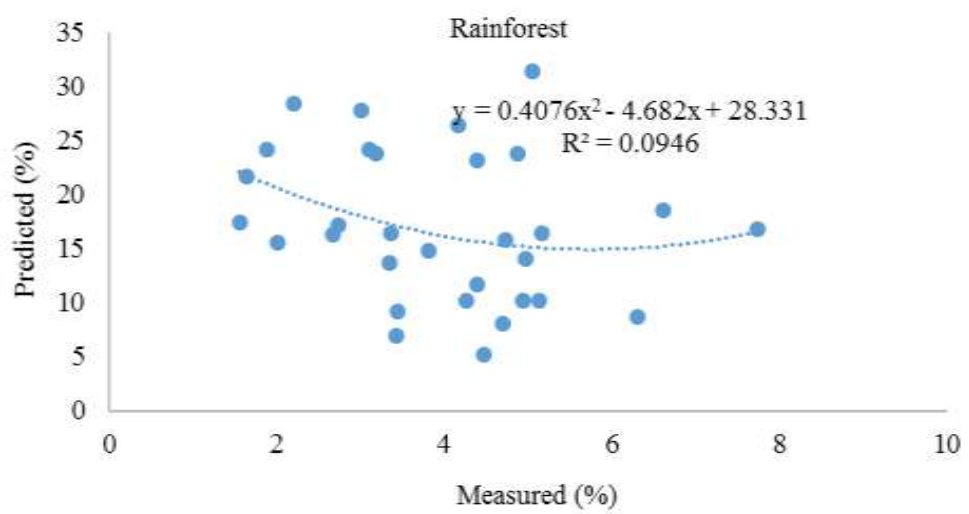

542 Fig. 5: Relationship between measured and predicted wilting point expressed by 543 polynomial regression 